\title{
DETERMINANTS INFLUENCING CONSUMER'S LOYALTY TOWARDS A PRIVATE BRAND*
}

\author{
Adi Alić ${ }^{3}$, Almir Peštek ${ }^{4}$ \& Ehlimana Merdićc
}

UDC / UDK: 658.626:658.89(497.6)

JEL classification / JEL klasifikacija: M31, E2

DOI: https://doi.org/10.22598/pi-be/2019.13.2.31

Original scientific paper / Izvorni znanstveni rad

Received / Primljeno: October 2, 2019 / 2. listopada 2019.

Accepted for publishing / Prihvaćeno za tisak: November 20, 2019 / 20.

studenog 2019.

\section{Summary}

In modern consumer society, consumers become all the more demanding with the right to possess the final statement on selection of a product, and thus the role of a brand as a means of communication is the key, since brands are powerful enough to attract and keep a consumer. Consumers create a relationship with a brand based on quality guarantee and positive experience. The main purpose of this paper is to explore determinants influencing consumer's loyalty towards a private brand. The research is based on private brand R-Time owned by the trade chain Robot. Data were collected through a field survey, and the sample consisted of 439 respondents. Data were analyzed using SEM analysis. The results of the survey show that the determinants of price and

* Paper presented at International Scientific Conference „TRADE PERSPECTIVES 2019: Business model innovations in domestic and international trade", November 2829, 2019, Zagreb, Croatia. Abstract of paper published in Conference Proceedings.

${ }^{3}$ Adi Alić, PhD, Assistant Professor, School of Economics and Business Sarajevo, Trg oslobođenja - Alija Izetbegović 1, 71000 Sarajevo, Bosnia and Herzegovina, E-mail: adi.alic@efsa.unsa.ba

${ }^{4}$ Almir Peštek, PhD, Full Professor, School of Economics and Business Sarajevo, Trg oslobođenja - Alija Izetbegović 1, 71000 Sarajevo, Bosnia and Herzegovina, E-mail: almir.pestek@efsa.unsa.ba

${ }^{5}$ Ehlimana Merdić, MA, Robot General Trading Co d.o.o., Rajlovačka cesta 41, 71000 Sarajevo, Bosnia and Herzegovina, E-mail: ehlimana_merdic@hotmail.com 
quality perception affect consumers' loyalty towards a product of the private brand $R$ Time, whereas there is no difference among tested ethnocentric and non-ethnocentric group of consumers. Building on our results, retailers are encouraged to scrutinize both price and quality perception of their own brands, in order to build long-term consumerbrand loyalty. The novelty and value of this research is reflected in the fact that the given results confirm that the size of the effect of price and quality perception on private brand loyalty among ethnocentric and non-ethnocentric consumers is not significant, so there is no need for retailers to focus on highlighting the brand's domestic origins. The main limitations of the study are related to data collection process, in terms of geographical coverage and product category. These limitations constitute areas for future research.

Keywords: brand, private brand, consumers, R-Time, Bosnia and Herzegovina

\section{INTRODUCTION}

Today there are a large number of products on the market that satisfy the wishes and demands of consumers, and there is almost no difference between the products. Consumers are becoming more demanding in the choice of products they have the final say as well, so the role of the brand as a means of communication has long been recognized, which has the power to attract and retain the consumer. Consumers establish a relationship with the brand based on quality assurance and positive experience. The true value of the brand is, in this sense, reflected in the perception of the consumer.

Brands and branding process in general are no longer exclusively related to wellknown manufacturers and their (national) brand names. In the last thirty years the socalled private brands are experiencing significant expansion and evolution. In simplistic terms, private brands are distributor-owned brands that hire manufacturers to produce the products to which the brand will be awarded. Private brands are synonymous with brands managed by someone other than the manufacturer. These are the most common brands of retailers and distributors, and are often referred to as private brands. Private brands owners require manufacturers to produce products with the right characteristics for them, and they (the retailers) will take care of the placement and all marketing activities. Thus, retailers are responsible for developing, planning, marketing managing and promotion of their own private brands.

The main initiator of the rapid growth of private brands is the expansion and consolidation of retailers. Increasing competition fight between retail chains has led to private brands being used as a means of improving competitiveness and generating greater profits. Introducing private (store) brands is one of the key elements of trade 
strategies to meet the needs of final consumers. Private brands have evolved over the years from generic products to products of almost the same quality as manufacturer brands.

Intensive changes observed in retail market in Bosnia and Herzegovina in recent decades have created the necessary prerequisites for strengthening retail chain brands, and therefore for developing, launching and strengthening store or private brands owned by them. Market presence of store/private brands of some market chains and the high level of recognition of this category by consumers indicates that most private/store brands in the retail market in $\mathrm{B} \& \mathrm{H}$ are in the stage of maturity or intensive growth.

Considering these changes, the problem of this paper is to investigate the determinants that influence consumer attitudes toward private brand R-Time of the domestic retail chain Robot. SEM analysis sought to determine whether price perceptions and perceived quality have a statistically significant effect on consumer loyalty to the analyzed private brand. The impact that price perception has on the perceived quality of a private brand is also analyzed. Finally, a multi-group consumer analysis was conducted, given the differences that exist in their belief in the quality of products under private brand of domestic origin. Determinants that show significant influence can serve retail chains to develop their marketing strategies more effectively.

This paper is organized as follows. First, we provide a literature review and hypotheses corresponding to research objectives. Then, the methodology is described. Next, the results are discussed, to end with some conclusions, implications and the research limitation.

\section{RESEARCH BACKGROUND AND HYPOTHESES}

\subsection{Private brands}

Globalization and the changing dynamics of the structure within retail forced retail businesses to rethink their business strategies and find new solutions that would allow them to maintain and improve their market positions. In an effort to preserve their profitability but also deliver additional value to consumers, retail businesses focused on introducing and developing their own brands. In this context, the creation of "strong" own brands becomes an imperative for successful differentiation of retail businesses and a means of improving their financial performance and competitive position (Mudambi, 2002).

A brand represents the name, expression, design, symbol, or any other characteristic that identifies the goods or services of one seller as different from the goods or services of other sellers (Aaker, 1996). It consists of the name and/or mark of the brand 
and other elements and activities that manufacturers assign to a product, service or idea to inform the market of their offer and uniqueness when compared to the competition. It refers to all relevant features of a product or service that differentiate it from products and services of another offerer. In this way, the brand gives the manufacturer the desired individuality, distinctiveness and image (Pavičić et al., 2014).

Even though they are private brands - brands per se, they have certain specificities in comparison to traditional manufacturers' (national) brands. The fundamental difference between national and private brands stems from the nature of the definition itself. Private brands are owned by a variety of market subjects (mainly marketing intermediaries), while national brand owners are "original" manufacturers. On the other hand, while manufacturer brands are available at various outlets in the market, the availability of private brand names is mainly related to their owner's distribution system (Herstein and Gamliel, 2004). Besides, manufacturers are mainly focused on a relatively small number of product categories, available in a number of outlets, and distributers have the ability to enter into a larger number of product categories, whose availability is limited to their own sales system (Tamilia et al., 2000). As a result, the identity of the manufacturer's brand is generally focused and consistent, while that of the private brand is broad, creating a potential threat to consistency.

Considering the specifics of private brands, there is a need for their separate conceptual definition. Basic and most commonly cited definition is the one offered by Morris (1979), which defines private brands as follows: "Consumer products, produced by, or produced for a distributor and sold under the distributor's brand or own market brand through own distribution places of a distributor." Apart to the name of a private brand and a store brand, the literature often uses terms personal brands, distributor brands, intermediary brands or yet "exclusive brands".

Previous researches examining the phenomenon of private brands from a consumer perspective most often aimed at identifying consumer profiles prone to private brands (Rao, 1969; Burger and Schott, 1972). Research efforts were focused on the study of three groups of factors that determine consumers' preferences for private brands, as follows (Martinez and Montaner, 2008):

(1) perceptual factors, including perceived quality of private brands, perception of price fairness, perception of oneself as a smart buyer, perceived risk associated with buying private brands;

(2) consumer psychographic characteristics such as consumer price sensitivity, consumer sensitivity to product value, risk preference, consumer preference for promotional actions, consumer loyalty to the retailer, consumer loyalty to the manufacturer, consumer loyalty to the brand; and 
(3) consumer demographic characteristics such as age, gender, family size or income.

It is important to emphasize that the role and importance of private brands, which are exclusively tied to a particular retail chain, has changed dramatically in recent decades. Private brands have evolved into fully equal alternatives, able to compete with manufacturer's brands not only in price but in quality as well (Quelch and Harding, 1996), which has resulted in an increase in the share of these brands in the market as well as their presence in almost all categories of products (Geyskens et al., 2010).

\subsection{Private brands loyalty}

Brand loyalty, as the ultimate goal of the branding process, occurs when the consumer consistently selects a particular brand in the set of available alternatives over a long period of time, i.e. when consumers do not consider other brands when making a purchase decision. As a long-term central element in marketing, Aaker (1991) defines brand loyalty simply as the attachment consumers feel to a brand. This is reflected in the degree to which consumers are prepared to replace the brand, especially when the brand is exposed to certain changes. Loyalty can be expressed through different levels, each requiring different marketing challenges and marketing activities for successful management and exploitation.

While some authors (see, e.g., Bandyopadhyay et al., 2005) see loyalty as a reflection of frequency and repeated pattern in purchasing behaviour, others (see, e.g., Lim and Razzaque, 1997) state that loyalty reflects consumer's attitude toward the object, such as brand. Furthermore, some authors (see, e.g., Weinstein, 1972) indicate that loyalty expressed as a brand attitude can cause purchase behaviour, while others (see, e.g., Dimitriades, 2006) point out that purchasing behaviour and attitude can be combined into a single macro construct. Notwithstanding the absence of a single attitude and different approaches to measuring the construct of loyalty, one can speak of behavioural loyalty, attitude-based loyalty, or a combination of them - composite loyalty.

- Behavioural loyalty, as historically the earliest approach to the concept, refers to consumer's repeated and systematic purchasing behaviour towards a particular brand. In doing so, repeated purchase behaviour over a long period of time is treated as an indicator of consumer loyalty (Brown, 1952).

- Attitude-based loyalty refers to positive beliefs and feelings towards a particular brand within the set of available alternatives (Dick and Basu, 1994), that is, a strong internal partiality of the consumer to the brand (Gounaris and Stathakopoulos, 2004). 
- Composite loyalty is a concept that integrates behavioural and attitude-based loyalty.

For the purpose of this paper, we highlight one-dimensional structure of the construct having behavioural aspect as a response behaviour caused by affect and cognition (psychological processes). Therefore, loyalty is a specific action occurring as a response to different stimuli, such as specific contemplation and emotions.

In a study of consumer behavioural loyalty to store brands, Labeaga et al. (2007) conclude that loyalty alone can be considered as a key factor in the growth of private brand equity. Specifically, once consumers try a brand, many of them continue to buy it. In this sense, private brands are able to gain behavioural consumer loyalty, even at a higher level than in comparison to manufacturer brands. Furthermore, consumers loyal to a private brand have a more favourable perception of the distributor umbrella brand (de Wulf et al., 2005). This leads to the conclusion that store brands can evoke a sense of satisfaction, loyalty and repetitive shopping behaviour, which will then be passed on to the loyalty to a store or retailer (Binninger, 2008). In this sense, research suggests an inseparable link between private brand and retail brand loyalty (Uncles and Ellis, 1989; Steenkamp and Dekimpe, 1997; Binninger, 2008).

\subsection{Antecedents of private brands loyalty}

Previous research, in the context of private brands identified a number of variables that are linked to private brand loyalty (brand awareness, perceived quality, perceived value, brand association, store loyalty, store image, perceived risks, price perception, price awareness, private brand satisfaction, attitude towards private brands, consumer demand for diversity, trust in private brand, commitment to private brand, etc.). It is obvious that these variables belong to the group of perceptual factors mentioned above, but also to the group of psychographic characteristics of the consumer. Considering the primary focus of our research, previous research that takes into account variables related to perceived quality and price perception is of interest.

Price and price perceptions are of particular importance for private brands, as their initial positioning is based on a low price strategy, seeking to attract a segment of price aware consumers with lower purchasing power. Private brands seek to position themselves as alternatives to manufacturer brands, based primarily on price as a differentiation factor. This is supported by the general consensus among authors that price is the key reason consumers make the decision to buy private brands (Burger and Schott, 1972; Burton et al., 1998; Sinha and Batra, 1999), as well as the fact that private brands perform better in product categories where consumers exhibit greater price sensitivity (Raju et al., 1995; Ailawadi et al., 2001; Erdem et al., 2004). Price is also an element 
most commonly used by consumers when they perceive differences between private and manufacturer brands, whether they are consumers who prefer private or manufacturer brands (Nenycz-Thiel and Romaniuk, 2009). In addition, lower private brand prices can be particularly important for consumers in less developed countries, with lower income levels and, in this regard, lower purchasing power (Fontenelle, 1996). Private brands can also influence and change consumer price sensitivity and overall price elasticity of demand (Pauwels and Srinivasan, 2004), especially due to the fact that through competitive relations with manufacturer brands price promotional activities are intensified. They also affect the lowering of manufacturer brands, which also contributes to the overall well-being of consumers.

Theoretical and empirical evidence confirms that price perception is a significant factor of consumer loyalty to a particular brand (e.g., Keaveney, 1995; Varki and Colgate, 2001). Anselmsson and Johansson (2009) confirm that consumer loyalty to a private brand is significantly influenced by the fact that consumers perceive the purchase of these brands as appropriate value for money, with the additional conclusion that a higher price sensitivity of consumers also determines the intensity of private brand loyalty. Beristain and Zorrilla (2011), empirically prove the existence of statistically significant positive relationship between price perception of private brand and consumer loyalty to the same.

In line with the importance of private brands in the strategy of retailers, the need to integrate and apply the general principles and elements of branding, as well as the general principles and principles of marketing, is recognized over time. In this sense, most marketers are undoubtedly moving upstream on the scale, changing their strategic focus and seeking to improve the quality level of their private brands, which directly compete with the manufacturer brands (Dunne and Narasimhan, 1999; Apelbaum et al., 2003), resulting in exponential growth of these brands. Research indicates that apart from the common view that private brands do not have a positive image in terms of quality, consumers are losing interest in manufacturer brands precisely because private brand quality has been radically improved in recent years (Vaidyanathan and Aggarwal, 2000; Ghose and Lowengart, 2001).

In the context of the foregoing, research indicates that perceived quality has a strategic effect on brand equity in terms of increasing consumer loyalty to the brand (Kayaman and Arasli, 2007). Numerous previous studies (Lassar et al., 1995; Richardson et al., 1996; Ailawadi and Keller 2004; Netemeyer et al. 2004; Buil et al., 2008; Anselmsson and Johansson, 2009; Thong and Hawley, 2009; Girard et al., 2017) confirm that, among other factors analyzed, higher level of perceived quality contributes to private brands loyalty.

Finally, the relationship between product quality and monetary costs forms the basis for consumers' perception of the value that customers receive for money spent. Price 
is most often linked to perceived quality, with consumers actually using price as a signal of product quality. When it comes to private brands, it can be stated that their success depends on their ability to offer an adequate level of quality at an attractive price. In this regard, Beristain and Zorrilla (2011) empirically confirm that consumer perceptions of the affordability of a private brand have a positive effect on the perceived quality of the brand.

Country of origin, as an integral part of a brand, can act as a moderating variable and affect the relationship between price perception and perceived quality of a private brand. Consumers may attach less or greater importance to the country of origin of the brand, or be ethnocentric to a greater or lesser extent. There is a huge stream of researchers on the effect of country of origin in the literature (for comprehensive reviews of country of origin effects, see, for example, Verlegh and Steenkamp, 1999; Papadopoulos and Heslop, 2003). Nevertheless, research into the role of country of origin in the context of private brands is lacking. In this respect, this study attaches particular importance to the analysis of differences between two groups of consumers in terms of belief in the quality of products of domestic origin. This is particularly important given the research findings of Nikolić et al. (2014), according to which BH consumers want to know who are producers (brand or country of origin); they are very ethnocentric, they believe that $\mathrm{BH}$ has the best traditional products; that people should buy domestic products to support BH economy, and when they cannot buy BH products, they should buy the products made in the Region of former Yugoslavia/West Balkans.

\subsection{Hypotheses}

In our study, we will test the effect of two dimensions ('perceived price' and 'perceived quality') on brand loyalty, with the focus on private brand R-Time. Drawing upon the previous research findings, we expect that certain consumer perception characteristics of a private brand trigger greater brand loyalty. Influence of price perception to the perceived quality and the difference between two groups of consumers is additionally analysed considering the degree of belief in the quality of private brand of domestic origin. On the basis of literature review, we propose the following hypotheses:

H1: Private brand price perception is positively related to private brand quality perception, for all consumers regardless of their belief in private brand of domestic origin.

$\mathrm{H} 2$ : Private brand price perception is positively related to private brand loyalty, for all consumers regardless of their belief in private brand of domestic origin. $\mathrm{H} 3$ : Private brand quality perception is positively related to private brand loyalty, for all consumers regardless of their belief in private brand of domestic origin. 
H4: There are differences in the size of the effect between private brand price perception and private brand loyalty regarding consumers' belief in private brand of domestic origin.

H5: There are differences in the size of the effect between private brand quality perception and private brand loyalty regarding consumers' belief in private brand of domestic origin.

\section{METHODOLOGY AND FINDINGS}

\subsection{Research setting}

In this study we selected private brand R-Time, owned by Robot, domestic trade chain, which has been operating since 1995 in the market of Bosnia and Herzegovina and currently has 25 sales centres across the country. Basic activity of Robot is wholesale and retail of technical goods, consumer goods and food products as well as providing services within their own shopping centres (retail chains). In 2015 company Robot decided to create private brand, R-Time. The R-Time brand compromises a widespread, range of products, mainly in the categories of food products and hygiene. For the purpose of this study we chose food product category (i.e., sugar), which is a leading category in terms of market growth, according to the analysis of available secondary data on market share and growth rates of private brands in a specific category in Bosnia and Herzegovina.

\subsection{Data collection and sample}

Data to test the research hypotheses was collected using a cross-sectional instore intercept survey among consumers residing in the city of Sarajevo (Bosnia and Herzegovina). Stationed at the point of data collection, two assistants, with general training in market research, captured customers whom they asked to complete a selfadministered questionnaire that took about $10 \mathrm{~min}$. The surveys were carried out at three different stores belonging to retail chain Robot. Upon approaching the respondents, the interviewers identified themselves, explained the purpose of the research, and provided respondents with the definition of private brands. To minimize the potential bias due to non-probability sampling, interviews were conducted on both weekdays and weekends during morning and late afternoon/evening hours. At the end of fieldwork, a total of 439 usable questionnaires were obtained, 224 for "ethnocentric" consumers and 215 for "nonethnocentric" category of consumers. The sample was slightly skewed towards females (63.6\% were females, and $36.4 \%$ were males). This unequal gender distribution of the sample is in line with the assumption that women are usually more responsible for conducting the shopping for a household than their male counterparts (Beneke, 2013). In 
terms of age, $18.4 \%$ of respondents are between 20 - 30 years old; $33.2 \%$ between 31 $40 ; 35.1 \%$ between 41-50; and $13.3 \%$ over 51 years old. Regarding educational level, $31.9 \%$ of respondents have a high school or less, whilst $68.1 \%$ have at least a bachelor's degree. Considering family average income, distribution is quite equal (under BAM 1,000 -22.4\%; BAM 1,001-1,500 - 31.2\%; BAM 1,501-2,000 - 29.7\%; BAM 2,000+ - 16.7\%).

\subsection{Research instrument}

Questionnaire created for this research was divided into two sections. The first part of the questionnaire deals with the measurement of the constructs of the interest: private brand price perception, private brand quality perception and private brand loyalty. To measure price perception, we adopted three items from the scale by Herrmann and others (2007), formulated to reflect consumer perception compared to relative comparison of price with other brands, connectivity with the perceived performance or quality of a particular product, as well as compliance with previous consumer expectations. For perceived quality we used the Yoo and Donthu (2001) scale (also used by Thong and Hawley (2009)). Following behavioural aspect of the definition of loyalty, we used three items scale adopted from Gómez and Rubio (2010). All the items were measured on a seven point Likert scale, from 1 totally disagree to 7 totally agree. We also additionally used one dichotomous variable ("I prefer products under the private brand R-Time more because it is a home-made brand"), in order to categorize respondents into two general categories, which we labelled as: ethnocentric and non-ethnocentric consumers. The second part of the questionnaire presents respondents' demographic information (gender, age, income, education), each measured via a categorisation scheme.

\section{RESULTS}

This section focuses on the presentation and analysis of data obtained from research and provides interpretation of the main findings. Following Anderson and Gerbing (1988) methodological suggestion, the two-step approach for assessing structural equation models was employed. The first stage involves the assessment of the measurement model, and the second stage proceeds to test the structural relationships (hypotheses) among the latent constructs. Moreover, a multi-group analysis was carried out for ethnocentric and non-ethnocentric consumers. The analysis was performed using a program AMOS.

Prior to measurement model analysis testing the reliability of measuring scales was performed, by applying Cronbach alpha coefficient test. As shown in Table 1 the 
standardized factor loading of items (manifest variables) ranged from 0.626 and 0.972 , and all were statistically significant $(\mathrm{p}<0.001)$.

Table 1. Standardized factor loadings and Cronbach alpha

\begin{tabular}{|c|c|c|c|c|}
\hline Constructs & Code & Manifest variables and dimensions & $\lambda$ & Alpha \\
\hline \multirow{3}{*}{$\begin{array}{l}\text { Brand Loyalty } \\
\text { (BL) }\end{array}$} & bl1 & I consider myself loyal to $\mathrm{X}$ private brand & 0.740 & 0.754 \\
\hline & b12 & $\begin{array}{l}\text { I will not buy products from other retailers, } \\
\text { if I can buy the same item at X stores }\end{array}$ & 0.626 & \\
\hline & bl3 & $\mathrm{X}$ stores would be my first choice & 0.822 & \\
\hline \multirow{3}{*}{$\begin{array}{l}\text { Quality } \\
\text { perception } \\
\text { (PQ) }\end{array}$} & qp1 & $\begin{array}{l}\text { I believe in the quality of sugar by private } \\
\text { brand Robot }\end{array}$ & 0.968 & 0.963 \\
\hline & qp2 & $\begin{array}{l}\text { Sugar by private brand Robot sugar is high } \\
\text { quality }\end{array}$ & 0.913 & \\
\hline & qp3 & $\begin{array}{l}\text { Sugar by private brand Robot sugar has } \\
\text { exceptional features }\end{array}$ & 0.972 & \\
\hline \multirow{3}{*}{$\begin{array}{l}\text { Price } \\
\text { Perception } \\
(\mathrm{PP})\end{array}$} & pp1 & $\begin{array}{l}\text { Price of sugar by private brand Robot is in } \\
\text { accordance with product's performances }\end{array}$ & 0.776 & 0.844 \\
\hline & pp2 & $\begin{array}{l}\text { Price of sugar by private brand Robot is in } \\
\text { accordance with my expectations }\end{array}$ & 0.876 & \\
\hline & pp3 & $\begin{array}{l}\text { Price of sugar by private brand Robot } \\
\text { reflects good value for money in } \\
\text { comparison to other sugar brands }\end{array}$ & 0.793 & \\
\hline
\end{tabular}

Source: Author's elaboration

Measurement model. To assess the reliability, convergent validity, and discriminant validity of constructs of interest, Confirmatory factor analysis (CFA) was employed. The overall fit of the measurement model to data was acceptable. Normed chisquare value $\left(\chi^{2} / \mathrm{df}\right)$ of less than 5.0 has been suggested to indicate an adequate model fit (Schumacker and Lomax, 2004), as it is case in our study $\left(\chi^{2}=110.805, \mathrm{df}=24, \mathrm{p}<0.001\right)$. The value of other fit indices, Comparative Fit Index - CFI (0.970), Tucker-Lewis index - TLI (0.956), Goodness-of-fit index- GFI (0.946), and the Standardized Root Mean Squared Residual - SRMR (0.0421) showed the model fit the data adequately, according to model evaluation criteria suggested by Hair and others (2010).

We then assessed construct's internal consistency and validity. All constructs were deemed to be highly consistent and reliable as their composite reliability (CR) scores were above the recommended cut-off value of 0.7 (Bagozzi and Yi, 2012). According to Hair and others (2010), convergent validity is satisfied if the average variance extracted (AVE) is greater than 0.5. As shown in Table 2, Average variance extracted (AVE) of the three latent constructs (price perception, perceived quality, brand loyalty) ranged from 
0.538 to 0.905 . These findings suggest that convergent validity is satisfied. Discriminant validity was assessed by comparing the square-root AVE of each construct to its correlations with other constructs (Fornell and Larcker, 1981). The results showed that discriminant validity of constructs is supported as the square-root AVE of each construct is greater than the correlations between that construct and any other construct. Table 2 displays CR, AVE, square-root AVE and correlation values, supporting reliability, convergent and discriminant validity of constructs.

Table 2. Reliability, convergent and discriminant validity of constructs

\begin{tabular}{lcc|ccc}
\hline & \multicolumn{2}{c|}{$\begin{array}{c}\text { Composite reliability and } \\
\text { convergent validity }\end{array}$} & \multicolumn{3}{c}{ Discriminant validity $^{\text {a }}$} \\
\hline Construct & CR & AVE & PP & QP & BL \\
\hline Price Perception(PP) & 0.856 & 0.666 & $\mathbf{0 . 8 1 6}^{\mathbf{a}}$ & & \\
Quality Perception(QP) & 0.966 & 0.905 & 0.334 & $\mathbf{0 . 9 5 1}$ & \\
Brand Loyalty(BL) & 0.776 & 0.538 & 0.675 & 0.423 & $\mathbf{0 . 7 3 4}$ \\
\hline \multicolumn{7}{l}{ Note: ${ }^{a}$ Square-root AVE values are in diagonals (bold) and correlations (r) are off diagonal } \\
values
\end{tabular}

Source: Author's elaboration

Structural model. Once the measurement model was validated, subsequent structural equation modelling (SEM) analyses were conducted to test the hypotheses. The fitting indices of the structural model are as follows: $\chi^{2}=110.805 ; \mathrm{df}=24 ; \mathrm{p}=0.000$; CFI $=0.970 ; \mathrm{TLI}=0.956 ; \mathrm{GFI}=0.946 ; \mathrm{SRMR}=0.0421$. These findings demonstrate that the model's fit is satisfactory. Thus, it was deemed appropriate to test the hypothesized paths. Furthermore, we found that our model explains $50 \%$ of brand loyalty, suggesting that the structural model exhibits the adequate level of explanatory power.

Table 3. Hypotheses testing

\begin{tabular}{llcl}
\hline $\begin{array}{l}\text { Causal relationship (standardized } \\
\text { coefficient) }\end{array}$ & Total sample & $\begin{array}{c}\text { Ethnocentric } \\
\text { consumers }\end{array}$ & $\begin{array}{c}\text { Non- } \\
\text { ethnocentric } \\
\text { consumers }\end{array}$ \\
\hline $\begin{array}{l}\text { Price perception } \rightarrow \text { Quality } \\
\text { perception }\end{array}$ & $\beta=0.334^{* * *}$ & $\mathrm{~B}_{\mathrm{ET}}=0.426^{* * *}$ & $\mathrm{~B}_{\mathrm{NET}}=0.267 * * *$ \\
\hline Price perception $\rightarrow$ Brand loyalty & $\beta=0.601 * * *$ & $\mathrm{~B}_{\mathrm{ET}}=0.643^{* * *}$ & $\mathrm{~B}_{\mathrm{NET}}=0.517 * * *$ \\
\hline Quality perception $\rightarrow$ Brand loyalty & $\beta=0.223^{* * *}$ & $\mathrm{~B}_{\mathrm{ET}}=0.279^{* * *}$ & $\mathrm{~B}_{\mathrm{NET}}=0.221 * *$ \\
\hline Notes: ***p $<0.001 ; * * \mathrm{p}<0.05 ;$ & & & \\
\hline Source: Author's elaboration & & & \\
\hline
\end{tabular}


As predicted by hypothesis $\mathrm{H} 1$, a positive relationship between price perception and quality perception was supported for both types of consumers $(\beta=0.334 ; p<0.001)$. Price perception was also found to have a statistically significant positive influence on brand loyalty for both types of consumers $(\beta=0.601 ; \mathrm{p}<0.001)$, providing the support for hypothesis H2. Finally, a positive relationship between quality perception and brand loyalty was supported for both types of consumers $(\beta=0.223 ; \mathrm{p}<0.001)$, providing the support for hypothesis H3.

The second objective of the present study was to analyse the influence of the consumers' belief in brands of domestic origin (ethnocentric vs. non-ethnocentric) on the relationship between price perception, quality perception and brand loyalty. Therefore, group comparisons were made between ethnocentric and non-ethnocentric consumers, using structural equation modelling. The $\chi^{2}$ difference test indicated that there is no statistically significant difference between the ethnocentric and non-ethnocentric in the effect of private brand price perception on brand loyalty $\left(\chi^{2}=0.370, \mathrm{df}=1, \mathrm{p}=0.534\right)$ as well in the effect of private brand quality perception on brand loyalty $\left(\chi^{2}=0.327, \mathrm{df}=1\right.$, $\mathrm{p}=0.567$ ). Therefore, the hypotheses H4 and H5 are not supported.

\section{CONCLUSION}

Brand loyalty is definitely key determinant of purchase behaviour of consumers (Tellis, 1988). Findings obtained in previous studies indicate that brand loyalty leads to certain marketing advantages, such as reducing marketing costs, generating more new customers, giving greater trade leverage, increasing market share and relative price, reducing search motivation, providing favourable word of mouth, and generating greater resistance of loyal customers toward competitive strategies (Aaker, 1991; Dick and Basu, 1994; Chaudhuri and Holbrook, 2001).

A few previous studies addressed the factors that influence private brand loyalty. Thus, for example, Binninger (2008) points to a direct positive relationship between consumer satisfaction with a brand and consumer loyalty. Anselmsson and Johansson (2009) state that perceived quality, perceived value, price sensitivity of consumers and consumer loyalty to the private brand positively influence consumer's store brand loyalty. According to the conducted research, Gómez and Rubio (2010) show that apart from the attitude, private brand loyalty is positively influenced by seeking diversity by the consumers, loyalty to the retailer, trust in the private brand, and commitment to the brand, while the propensity for promotional activities has a negative impact.

In this study, we applied the construct of brand loyalty to private brands, based on the premise that consumers are able to create strong relationships with private brands 
in the same way as they are creating relationships with national brands. This study enables us to deepen our understanding of how price perception and quality perception can lead to the formation of a behavioural loyalty toward a private brand. A special contribution derives from the analysis of influence which country of private brand origin, as moderating variable has to the previously set relations.

Regarding H1: "Private brand price perception is positively related to private brand quality perception, for all consumers regardless their belief in private brand of domestic origin", our findings suggest that there is a significant positive influence of price perception on quality perception o for private brands. Unlike the conventional view that a lower price signals a lower quality of a product or service, in the context of private brands it is reasonable to assume that it is inversely related, in the sense that price advantage will have a positive contribution to the perception of quality. These findings are in line with previous studies arguing that there is a positive relationship between private brand price perception and private brand quality perception (Beristain and Zorrilla, 2011; Calvo-Porral et al., 2013).

In relation to $\mathrm{H} 2$ : "Private brand price perception is positively related to private brand loyalty, for all consumers regardless of their belief in private brand of domestic origin“, our findings suggest there is a significant positive influence of price perception on brand loyalty for private brands. These findings are in line with previous, Beristain and Zorrilla (2011) study which empirically proves the existence of statistically significant positive relationship between price perception of private brand and consumer loyalty to the same.

In relation to $\mathrm{H} 3$ : "Private brand quality perception is positively related to private brand loyalty, for all consumers regardless of their belief in private brand of domestic origin", our findings suggest there is a significant positive influence of quality perception on brand loyalty for private brands. These findings are in line with the findings of numerous previous studies (Lassar et al., 1995; Richardson et al., 1996; Ailawadi and Keller, 2004; Netemeyer et al. 2004; Buil et al., 2008; Anselmsson and Johansson, 2009; Tong and Hawley 2009; Girard et al., 2017).

Finally, regarding $\mathrm{H} 4$ and $\mathrm{H} 5$, our findings suggest there is no statistically significant difference between the ethnocentric and non-ethnocentric customers in the effect of private brand price perception on brand loyalty (regarding consumers' belief in domestic origin of private brand). Nevertheless, research conducted by Nikolić, Uzunović i Spaho (2014) shows that BH customers want to know who are producers (brand or country of origin), they are very ethnocentric and they believe that BH has the best traditional products, the findings of our research do not confirm that, at least concerning the sample private brand. The reason can be the fact that they previously developed high 
degree of loyalty towards analysed store brand, and in that sense the influence of their belief in domestic origin of the brand becomes negligible.

The present study provides marketing managers of private brands some insights into how to improve brand loyalty. Our results reinforce the notion of the importance of perceptive factors attached to brand in the formation of loyalty toward a brand for private brands. Building on our results, retailers are encouraged to scrutinize both price and quality perception of their own brands, in order to build long-term consumer-brand loyalty. On the other hand, a closer examination of the differences between the size of the effect of price and quality perception on private brand loyalty among ethnocentric and non-ethnocentric consumers suggests that there is no significant need for retailers to focus on highlighting the brand's domestic origins

This research has a number of limitations, which constitute areas for future research. First, data were collected exclusively in the retailer's stores located in the city of Sarajevo. Therefore, results may differ concerning other domestic, regional and national markets as well as other product categories. Future studies are, therefore, welcomed in expanding the domain of this research with respect to the geographical coverage and product category. Second, the study was carried out on a convenience sample, and future studies could improve in this regard. Third, it is also possible that the frequency with which consumers use a brand, as well as how long they have been using it, affect their belief in domestic origin of private brand. Since this issue was not controlled in the current study and has also been neglected in past research, it should be addressed in future research endeavours. Hence, future studies might address this issue.

\section{REFERENCES:}

1. Aaker, D.A. (1991). Managing Brand Equity. Capitalizing on the Value of Brand Name. New York: The Free Press.

2. Aaker, D.A. (1996). Building Strong Brands. New York: The Free Press.

3. Ailawadi, K.L. and Keller, K.L. (2004). Understanding retail branding: Conceptual insights and research priorities. Journal of Retailing, 80(4), pp. 331342. https://doi.org/10.1016/j.jretai.2004.10.008.

4. Ailawadi, K.L., Neslin, S.A. and Gedenk, K. (2001). Pursuing the valueconscious consumer: Store brands versus national brand promotions. Journal of Marketing, 65(1), pp. 71-89. https://doi.org/10.1509/jmkg.65.1.71.18132.

5. Anderson, J. and Gerbing, D. (1988). Structural equation modeling in practice: a review and recommended two-step approach. Psychological Bulletin, 103(3), pp. 411- 423. https://doi.org/10.1037//0033-2909.103.3.411. 
6. Anselmsson, J. and Johansson, U. (2009). Third generation of retailer brands retailer expectations and consumer response. British Food Journal, 111(7), pp. 717-734. https://doi.org/10.1108/00070700910972396.

7. Apelbaum, E., Eitan, G. and Prasad, A.N. (2003). The Effects of Expert Quality Evaluations Versus Brand Name on Price Premiums. The Journal of Product and Brand Management, 12(2/3), pp. 154-165. https://doi.org/10.1108/10610420310476915.

8. Bagozzi, R. and Yi, Y. (2012). Specification, Evaluation, and Interpretation of Structural Equation Models. Journal of the Academy of Marketing Science, 40(1), pp. 8-34. https://doi.org/10.1007/s11747-011-0278-x.

9. Bandyopadhyay, S., Gupta, K. and Dube, L. (2005). Does brand loyalty influence double jeopardy? A theoretical and empirical study. Journal of Product \& Brand Management, 14(7), pp. 414-423. https://doi.org/10.1108/10610420510633369.

10. Beneke, J. (2013). A closer inspection of the impact of perceived risk on purchase intention of premium private label brands: The effect of age, gender, income and racial group. Journal of Business and Retail Management Research, 7(2), pp. 44-56.

11. Beristain, J.J. and Zorrilla, P. (2011). The relationship between store image and store brand equity: A conceptual framework and evidence from hypermarkets. Journal of Retailing and Consumer Services, 18(6), pp. 562-574. https://doi.org/10.1016/j.jretconser.2011.08.005.

12. Binninger, A.S. (2008). Exploring the relationships between retail brands and consumer store loyalty. International Journal of Retail \& Distribution Management, 36(2), pp. 94-110. https://doi.org/10.1108/09590550810853057.

13. Brown, G.S. (1952). Brand loyalty - Fact or fiction?. Advertising Age, 23, pp. 53-56.

14. Buil, I., de Chernatony, L. and Martinez, E. (2008). A cross-national validation of the consumer-based brand equity scale. Journal of Product \& Brand Management, 17(6), pp. 384-392. https://doi.org/10.1108/10610420810904121.

15. Burger, P.C. and Schott, B. (1972). Can private brand buyers be identified?. Journal of Marketing Research, 9, pp. 219-222. https://doi.org/10.1177/002224377200900217.

16. Burton, S., Lichtenstein, D.R., Netemeyer, R.G. and Garretson, J.A. (1998). A scale for measuring attitude toward private label products and an examination of its psychological and behavioral correlates. Journal of the Academy of Marketing Science, 26(4), pp. 293-306. https://doi.org/10.1177/0092070398264003. 
17. Calvo-Porral, C., Martinez-Fernandez, V., Juanatey-Boga, O. and LevyMangin, J-P. (2013). What matters to store Brand Equity? An approach to Spanish large retailing in adownturn context. Investigaciones Europeas de Direccion y Economia de la Empresa, 19, pp. 136-146. https://doi.org/10.1016/j.iedee.2013.03.001.

18. Chaudhuri, A. and Holbrook, M.B. (2001). The chain of effects from brand trust and brand affect to brand performance: The role of brand loyalty. Journal of Marketing, 65(2), pp. 81-93. https://doi.org/10.1509/jmkg.65.2.81.18255.

19. De Wulf, K., Odekerken-Schroder, G., Goedertier, F. and Van Ossel, G. (2005). Consumer perceptions of store brands versus national brands. Journal of Consumer Marketing, 22(4), pp. 223-232. https://doi.org/10.1108/07363760510605335.

20. Dick, A.S. and Basu, K. (1994). Customer Loyalty: Toward an Integrated Conceptual Framework. Journal of the Academy of Marketing Science, 22(2), pp. 99-113. https://doi.org/10.1177/0092070394222001.

21. Dimitriades, Z.S. (2006). Customer satisfaction, loyalty and commitment in service organizations: some evidence from Greece. Management Research News, 29(12), pp. 782-800. https://doi.org/10.1108/01409170610717817.

22. Dunne, D. and Narasimham, C. (1999). The new appeal of private labels. Harvard Business Review, 77(3), pp. 41-48.

23. Erdem, T., Zhao, Y. and Valenzuela, A. (2004). Performance of store brands: A crosscountry analysis of consumer store-brand preferences, perceptions, and risk. Journal of Marketing Research, 41(1), pp. 86-100. https://doi.org/10.1509/jmkr.41.1.86.25087.

24. Fontenelle, S.M. (1996). Private labels and consumer benefits- The Brazilian Experience. Advances in Consumer Research, 23(1), pp. 97-103.

25. Fornell, C. and Larcker, D.F. (1981). Evaluating Structural Equation Models with Unobservable Variables and Measurement Error. Journal of MarketingResearch, $18(1), \quad$ pp. 39-50. https://doi.org/10.1177/002224378101800104.

26. Geyskens, I., Gielens, K. and Gijsbrechts, E. (2010). Proliferating private-label portfolios: How introducing economy and premium private labels influences brand choice. Journal of Marketing Research, 47(5), pp. 791-807. https://doi.org/10.1509/jmkr.47.5.791.

27. Ghose, S. and Lowengart, O. (2001). Perceptual positioning of international, national and private brands in a growing international market: an empirical study. Journal of Brand Management, 9(1), pp. 45-62. https://doi.org/10.1057/palgrave.bm.2540051. 
28. Girard, T., Trapp, P., Gulsoy, T. and Boyt, E. (2017). Consumer-Based Brand Equity of a Private-Label Brand: Measuring and Examining Determinants. Journal of Marketing Theory and Practice, 25(1), pp. 39-56. https://doi.org/10.1080/10696679.2016.1236662.

29. Gómez, M. and Rubio, N. (2010). Re-thinking the relationship between store brand attitude and store brand loyalty: a simultaneous approach. The International Review of Retail, Distribution and Consumer Research, 20(5), pp. 515-534. https://doi.org/10.1080/09593969.2010.520507.

30. Gounaris, S. and Stathakopoulos, V. (2004). Antecedents and Consequences of Brand Loyalty: An Empirical Study. Journal of Brand Management, 11(4), pp. 283-307. https://doi.org/10.1057/palgrave.bm.2540174.

31. Hair, J.F., Black, W.C., Babin, B.J. and Anderson, R.E. (2010). Multivariate data analysis. 7th ed. Upper Saddle River, NJ: Pearson Prentice Hall.

32. Herrmann, A., Xia, L., Monroe, K.B. and Huber. F. (2007). The Influence of Price Fairness on Consumer Satisfaction: An Empirical Test in the Context of Automobile Purchases. Journal of Product \& Brand Management, 16(1), pp. 4958. https://doi.org/10.1108/10610420710731151.

33. Herstein, R. and Gamliel, E. (2004). An investigation of private branding as a global phenomenon. Journal of Euromarketing, 13(49, pp 59-77. https://doi.org/10.1300/J037v13n04_04.

34. Kayaman, R. and Arasli, H. (2007). Customer Based Brand Equity: Evidence from the Hotel Industry. Managing Service Quality, 17(1), pp. 92-109. https://doi.org/10.1108/09604520710720692.

35. Keaveney, S.M. (1995). Customer Behavior in Services Industries: An Exploratory Study. Journal of Marketing, 59(2), pp. 71-82. https://doi.org/10.1177/002224299505900206.

36. Labeaga, J.M., Lado, N. and Martos, M. (2007). Behavioural loyalty towards store brands. Journal of Retailing and Consumer Services, 14(5), pp. 347-356. https://doi.org/10.1016/j.jretconser.2007.01.001.

37. Lassar, W., Mittal, B. and Sharma, A. (1995). Measuring Customer-based Brand Equity. Journal of Consumer Marketing, 12(4), pp. 11-19. https://doi.org/10.1108/07363769510095270.

38. Lim, K.S. and Razzaque, M. (1997). Brand loyalty and situational effects: an interactionist perspective. Journal of International Consumer Marketing, 9(4), pp. 95-115. https://doi.org/10.1300/J046v09n04_06.

39. Martinez, E. and Montaner, T. (2008). Characterisation of Spanish store brand consumers. International Journal of Retail \& Distribution Management, 36(6), pp. 447-493. https://doi.org/10.1108/09590550810873947. 
40. Morris, D. (1979). The Strategy of Own Brands. European Journal of Marketing, 13(2), pp. 59-78. https://doi.org/10.1108/EUM0000000004930.

41. Mudambi, S. (2002). Branding Importance in Business-to-Business Markets: Three Buyer Clusters. Industrial Marketing Management, 31(6), pp. 525-533. https://doi.org/10.1016/S0019-8501(02)00184-0.

42. Nenycz-Thiel, M. and Romaniuk, J. (2009). Perceptual categorization of private labels and national brands. Journal of Product and Brand Management, 18(4), pp. 251-261. https://doi.org/10.1108/10610420910972774.

43. Netemeyer, R., Krishnan, B., Pullig, C., Wang, G., Yagci, M., Dean, D., Ricks, J. and Wirth, F. (2004). Developing and validating measures of facets of customer-based brand equity. Journal of Business Research, 57(2), pp. 209-224. https://doi.org/10.1016/S0148-2963(01)00303-4.

44. Nikolić, A., Uzunović, M. and Spaho, N. (2014). Lifestyle pattern underlying organic and traditional food consumption. British Food Journal, 116(11), pp. 1748-1766. https://doi.org/10.1108/BFJ-02-2014-0085.

45. Papadopoulos, N. and Heslop, L.A. (2003). Country equity and product-country images: State of the art in research and implications, In: S.C. Jain, ed., Handbookof Research in International Marketing, Cheltenham: Elgar 2003, pp. 402-433.

46. Pauwels, K. and Srinivasan, S. (2004). Who benefits from store brand entry?. Marketing Science, 23(3), pp. 364-390. https://doi.org/10.1287/mksc.1030.0036.

47. Pavičić, J., Gnjidić, V. and Drašković, N. (2014). Osnove strateškog marketinga. Zagreb: Školska knjiga.

48. Quelch, J.A. and Harding, D. (1996). Brands versus private labels. Harvard Business Review, 74(1), pp. 99-109.

49. Raju, J.S., Sethuraman, R. and Dhar, S.K. (1995). The interaction and performance of store brands. Management Science, 41(6), pp. 957-978. https://doi.org/10.1287/mnsc.41.6.957.

50. Rao, T. (1969). Are some consumers more prone to purchase private brands?. Journal of Marketing Research, 57, pp 56-70. https://doi.org/10.2307/3150080.

51. Richardson, P., Jain, A.K. and Dick, A. (1996). Household store brand proneness: A framework. Journal of Retailing, 72(2), pp. 159-185. https://doi.org/10.1016/S0022-4359(96)90012-3.

52. Schumacker, R.E. and Lomax, R.G. (2004). A beginner's guide to structural equation modeling. 2nd ed., Mahwah, NJ: Lawrence Erlbaum Associates Publishers. 
53. Sinha, I. and Batra, R. (1999). The effect of consumer price consciousness on private label purchase. International Journal of Research in Marketing, 16(3), pp. 237-251. https://doi.org/10.1016/S0167-8116(99)00013-0.

54. Steenkamp, J-B.E.M. and Dekimpe, M. (1997). The increasing power of private labels: building loyalty and market share. Long Range Planning, 30(6), pp. 917930. https://doi.org/10.1016/S0024-6301(97)00077-0.

55. Tamilia, R.D., Corriveau, G. and Arguedas, L.E. (2000). Understanding the significance of private brands with particular reference to the canadian grocery market. WorkingPaper No.11, Montreal: University of Quebec, pp. 1-38.

56. Tellis, G.J. (1988). Advertising exposure, loyalty, and brand purchase: A twostage model of choice. Journal of Marketing Research, 25(2), pp. 134-144. https://doi.org/10.1177/002224378802500202.

57. Thong, X. and Hawley, J.M. (2009). Measuring customer-based brand equity: empirical evidence from the sportswear market in China. Journal of Product \& Brand Management, 18(4), pp. 262-271. https://doi.org/10.1108/10610420910972783.

58. Uncles, M.D. and Ellis, K. (1989). The buying of own-labels. European Journal of Marketing, 23(3), pp. 57-70. https://doi.org/10.1108/EUM0000000000561.

59. Vaidyanathan, R. and Aggarwal, P. (2000). Strategic brand alliances: implications of ingredient branding for national and private label brands. Journal of Product \& Brand Management, 9(4), pp. 214-228. https://doi.org/10.1108/10610420010344013.

60. Varki, S. and Colgate, M. (2001). The role of price perceptions in an integrated model of behavioral intentions. Journal of Service Research, 3(3), pp. 232-240. https://doi.org/10.1177/109467050133004.

61. Verlegh, P.W. and Steenkamp, J.E. (1999). A review and meta-analysis of country-of-origin research. Journal of Economic Psychology, 20(5), pp. 521546. https://doi.org/10.1016/S0167-4870(99)00023-9.

62. Weinstein, A.G. (1972). Predicting behavior from attitudes. The Public Opinion Quarterly, 36(3), pp. 355-360. https://doi.org/10.1086/268017.

63. Yoo, B. and Donthu, N. (2001). Developing and Validating a Multidimensional Consumer-Based Brand Equity Scale. Journal of Business Research, 52(1), pp. 1-14. https://doi.org/10.1016/S0148-2963(99)00098-3. 


\title{
DETERMINANTE UTJECAJA NA LOJALNOST POTROŠAČA PREMA PRIVATNIM MARKAMA
}

\author{
Adi Alić, Almir Peštek \& Ehlimana Merdić
}

\section{Sažetak}

U suvremenom potrošačkom društvu, potrošači postaju sve zahtjevniji $i$ oni imaju zadnju riječ u izboru proizvoda, pa je uloga marke kao sredstva komunikacije postala presudna, jer marke imaju snagu privući i zadržati potrošača. Potrošači uspostavljaju odnos s markom koji se zasniva na jamstvu kvalitete i pozitivnom iskustvu. Osnovna svrha rada jest istražiti determinante koje utječu na lojalnost potrošača prema privatnoj marki. Istraživanje je bazirano na privatnoj marki R-Time, trgovačkog lanca Robot. Podaci su prikupljeni putem strukturiranog upitnika i uzorak je obuhvatio 439 ispitanika. Podaci su analizirani primjenom metode modeliranja putem strukturalnih jednadžbi (SEM). Rezultati istraživanja su pokazali da determinante koje se odnose na cjenovnu percepciju i percepciju kvalitete utječu na lojalnost potrošača prema proizvodu pod privatnom markom R-Time, s tim da nije dokazano da postoji razlika između dvije testirane grupe potrošača - etnocentričnih i neetnocentričnih potrošača. Bazirano na rezultatima istraživanja, maloprodavači se potiču da vrlo pažljivo vode računa $i$ o cjenovnoj percepciji i o percepciji kvalitete njihovih privatnih marki, u cilju izgradnje dugoročne lojalnosti potrošača. Novitet $i$ vrijednost ovog istraživanja se ogleda $u$ činjenici da dobiveni rezultati potvrđuju da veličina utjecaja cjenovne percepcije $i$ percepcije kvalitete na potrošačku lojalnost privatnoj marki, između etnocentričnih $i$ neetnocentričnih potrošača, nije statistički signifikantna, tako da ne postoji potreba da maloprodavači stavljaju poseban fokus na domaće porijeklo privatne marke. Osnovna ograničenja ovog rada su u najvećoj mjeri vezana za proces prikupljanja podataka, a u smislu geografske pokrivenosti $i$ kategorije proizvoda. Data ograničenja svakako otvaraju područja za buduća istraživanja.

Ključne riječi: marka, privatna marka, potrošači, R-time, Bosna i Hercegovina. 